\title{
As we were or seeking what we ought to be? A practical theological rethinking of the communio sanctorum in the light of COVID-19
}

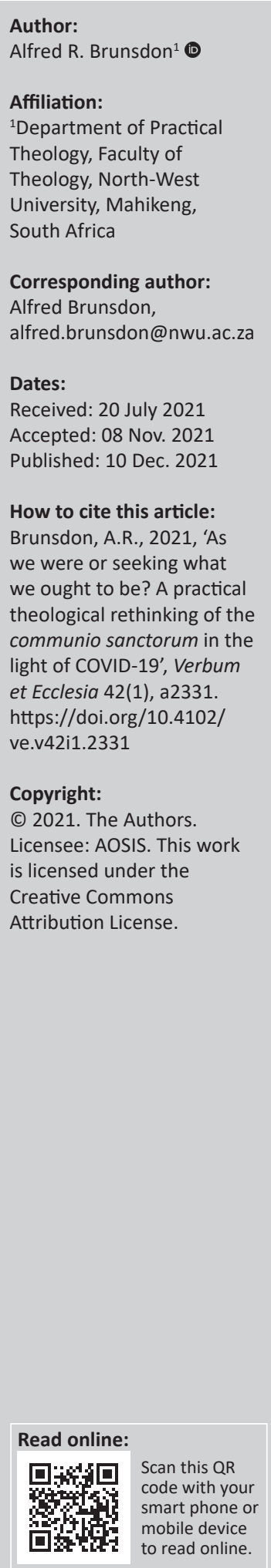

The focus of this article is on a 69 year old Dutch Reformed congregation in Lichtenburg (North West province), South Africa. It reflects on the congregation's understanding of the communio sanctorum, the practice of which was halted due to COVID-19. Initial responses to the crisis suggested a deep longing for the communio sanctorum and yearning among inactive church members to reconnect to the faith community. This created an expectation of a largescale return to public worship once social distancing measures were relaxed. Also that the leadership would pursue opportunities to reconnect inactive church members to the faith community post-COVID. It however transpired that the congregation was merely trying to restore its pre-COVID-19 homeostasis. A brief historical probe of the communio sanctorum is compared with results of a small-scale empirical enquiry into congregants' perceptions of the communio sanctorum from an insider-perspective. The article argues that the congregation may have missed an opportunity to re-imagine the communio sanctorum due to a reductionist view. It concludes by alluding to a need for a reframing of COVID-19 as a kairos moment with a view on a reorientation towards the meaning of the communio sanctorum.

Intradisciplinary and/or interdisciplinary implications: By engaging church's historical and empirical insights from an insider perspective of a South African congregation within a practical theological framework, the research challenges reductionist views of the communio sanctorum held by faith communities. The resultant view, that the communio sanctorum has both inward and missional meaning, has implications for post-COVID congregational studies and congregational praxeology.

Keywords: Dutch Reformed Church; COVID-19; social restrictions; Apostolicum; communio sanctorum; congregational life.

\section{Introduction}

This article presents a case study conducted in a local Dutch Reformed Church (DRC) in the North West province of South Africa, the DRC Lichtenburg East (DRCLE) in the light of COVID-19. It departs from experiences of the 'hard lock down' during 2020 that confronted the congregation with a suspension of public worship. In its 69 -year-old history, this was the very first time that the doors of the church were closed to the faith community. Although this measure was in accordance with national legislature, it did not soften the blow to leadership and congregation members who responded with reactions that reminded of typical grief symptoms such as shock, anger and denial about the course of events.

The thesis of this article is that the extraordinary circumstances presented by COVID-19 not only posed an existential crisis for faith communities, but simultaneously offered an opportunity to reimagine expressions of the communio sanctorum that historically became centred on public worship and entrenched in a reductionist ecclesial praxeology when viewed against the rich reformed theological heritage of the ninth article of the Apostolicum. It is argued that congregational practices that emerged during COVID-19, presented clues for exploring new avenues for a postCOVID-19 communio sanctorum. However, from an observer's (insider's) point of view, it seemed like the congregation only aspired to regain homeostasis during the ensuing relaxing of social restrictions. This rendered the question: As we were or seeking what we ought to be? Put differently, should the DRCLE (or faith communities in general) simply resettle into pre-COVID-19 praxeology or seek the deeper meaning of communio sanctorum post-COVID-19? It is argued that the latter should be pursued as COVID-19 not only presented challenges but also offered an opportunity for a reassessment of the meaning of the communio sanctorum. 


\section{Theoretical framework and research method}

The research was conducted in a practical theological framework where practical theology facilitates critical reflection on the practice of the church with a view on theory aimed at enhanced praxeology (Brunsdon 2017a:118; Heyns \& Pieterse 1990:6; Swinton \& Mowat 2016:25). Methodologically, the research was mindful of COVID-19 protocols, employing an insider approach, document study and a small scale empirical component.

The voice of the researcher is audible throughout the article from an insider perspective. Insider perspective research represents a form of qualitative research where there is a close link between the researcher and the 'culture' that is investigated (Chavez 2008:475). In this regard, the researcher has been an ordained minister in the congregation since 1997. Although he left ministry to become a full-time academic in 2012 , he lives in close union with this congregation in which he leads sermons on a regular basis, is married to the resident pastor and is a member of the church council. An insider perspective is used to provide continuity to the narrative and draws from knowledge, experiences and observations in the congregation which are presented from a reflective stance.

Apart from insider perspectives, unique documents pertaining to the specific congregation were also consulted. These included statistics and non-sensitive information from the congregation's Vestry-book, electronic membership database and different Yearbooks of the DRC. Permission to engage congregation resources was formally obtained from the church council. Additional data for the article were collected from relevant literature regarding church history and the confessional basis of the DRC.

A small-scale empirical section formed part of the research design in order to engage congregation members. After obtaining informed consent, a qualitative questionnaire, consisting of open-ended questions, gave purposively sampled members a voice in the research regarding their perceptions, understanding and experiences of the communio sanctorum pre-, mid- and post-COVID-19. The participation of congregation members was guided by an ethics framework based on the principles of informed consent, voluntary participation and a low risk of harm. In light of the researcher's institutional affiliation to the North-West University, a proposal was submitted to the Research Ethics Committee of the Faculty of Theology and an ethics number for the project was formally awarded (NWU-00760-21-A7).

\section{Research context}

The immediate context of the research is the DRCLE. The congregation is situated in a rural town of the North West province of South Africa named Lichtenburg that is mainly known as a maize-producing area. Proclaimed in 1873 (Raper, Möller \& Du Plessis 2014:275-276), the town became the focal point of fortune seekers after diamonds were discovered in the area in 1925. Previously, the area relied on agriculture, which eventually survived alluvial diamond mining that today is only found on a small scale in the region. Currently, the cement industry is also a major contributor to the local economy with at least three factories in operation, of which the French company Lafarge is one.

The congregation is the largest of the four Dutch Reformed congregations in the town, currently ministering to 998 souls of which 789 are adult confessing members and 209 children under the age of 17 (Yearbook of the DRC 2021:185). The congregation came into being in 1952 to serve the spiritual needs of Dutch Reformed residents of the suburb of Lichtenburg, known as Burgersdorp. Initially, the area was not very affluent and intentions to erect a church building were greeted with scepticism from the rest of the DRC community. The fact that this new congregation succeeded to erect a church building with a pipe-organ from their own funds, which was inaugurated in 1957, characterised this particular faith community as resilient with a strong will to be independent.

For the sake of an international reader audience, three perspectives on the larger denominational context of the congregation are of significance. It can first be observed that the DRC is a Protestant church that found its way to South Africa with the Dutch Settlers in 1652.

Equally important is the fact that the DRC bore a unique history that developed reciprocally with the social history of South Africa. From a church-historical perspective, this reciprocal relationship is probably best known for the close ties between the government and DRC that reached a high point in the late 1940s when the National Party, under the leadership of Dr D.F. Malan, came into power. The DRC's theological initiatives and support of segregated development in the ensuing apartheid years is well-documented, to the extent that it does not warrant a separate discussion here (Gaum 1997; Strauss 2020). It is small wonder that the DRC became anecdotally known as the 'National Party at prayer' (Kenny 2016; Strauss 2019). The DRC also became known as the religious home of white Afrikaans-speaking people in South Africa. Although a minority, the close ties to the ruling party (as most political leaders were DRC members) and theological sanction that white people were called by God for a specific task (Forster 2016) put members of the DRC in a perceived position of power.

These two perspectives are helpful in terms of understanding the third, namely that the DRC can currently be regarded as a church that finds itself in a dire position. Not only did it lose much of its strict Calvinistic spirit, but its influential position in South African society as well. The onset of these radical changes was signalled by internal and external factors. Internally, the DRC started to change its strict policies on the pivotal issues that characterised its symbiotic relationship with government. Its abandonment of the Biblical justification of apartheid and the 'opening' up of membership to all ethnic groups during the mid-1980s was arguably the main turning point. The immediate effect was an exodus of members from 
the 'mother church'. Some left out of protest. In this regard, the Afrikaans Protestant Church was formed on 27 June 1987, as protest against the DRC's abandonment of apartheid, when approximately 8000 members and 30 ministers left the DRC (Van der Merwe 2002:428). Authors such as Gaum (2002:241), put these figures much higher at 20000 members and 100 ministers. The longer term effect was disillusionment amongst members of the church, feeling that they were being misled by the church. 'Many people feel cheated and want to know, if the church lied to them about apartheid what else is it lying about?' (Leonard 2012). Members who felt this way continued the exodus that is steadily carrying on in the present, leading some observers to refer to the 'slow and steady death of the Dutch Reformed Church' (Leonard 2012).

Externally, the DRC was also be hard hit by the dawn of the new democracy in the mid-1990s that stripped the white minority of all privileged positions in society - and the DRC of its close partnership with the ruling government. Almost overnight, its white membership became embattled with coming to terms with a non-racial society, where they could only compete for a fair share, which on the grounds of numbers alone, translated into crises such as job losses and economic hardships. After a short-lived optimism about the newly found 'rainbow-nation' (Brunsdon 2017b:4), many new realities set in that left DRC members further disillusioned and deeply disappointed. Notable numbers of white South Africans sought a future abroad, which had a further negative impact on the already declining membership (Oosthuizen 2019). Together with growing secular thinking (Leonard 2012), previously fervent members gradually adopted a more neutral and less loyal relationship with the DRC.

Irrespective of these historical developments, the DRC is still regarded as the largest church of white Afrikaansspeaking people in the country (Steyn, Wepener \& Pieterse 2020:1). According to the Yearbook of the DRC (2021), there are currently 627390 adult confessing members, 165245 baptised children (under the age of 17) who belong to 1050 active congregations across the country that are divided into 9 synods and served by 1270 pastors. The DRC also has a synod in neighbouring Namibia with 44 congregations that are home to 14669 adult confessing members and 8147 baptised children (under the age of 17) served by 58 pastors. The combined number of members and pastors for South Africa is thus below a million (793 905). Based on the 2020 mid-year estimates of Statistics SA, which set the total white population of the country at 4679770 (7.8\% of the total population of 59622350), DRC members, thus approximately represent $17 \%$ of the white population and $1.3 \%$ of the total population.

Since the mid-1990s, DRC congregations and synods have started to show diverse thinking and expressions of worship, with some being more progressive or even liberal than others. In liberal-minded congregations, the conservative, strict and legalistic Calvinistic spirit of yore has seemingly perished. One example that can be mentioned is thinking on contentious issues such as same-sex relationships. Historically though, the DRC remained a church for white Afrikaans-speaking people. Despite its 'open' membership policy, members of mixed race is still a rarity.

\section{Pre-COVID-19 congregational life in the Dutch Reformed Church Lichtenburg East}

In terms of the mentioned diversity of the DRC, the DRCLE probably resorts on the less-liberal side of the spectrum, mainly on grounds of the organisation, worship style and theological viewpoints held by the congregation on contentious issues.

Organisationally, the DRCLE is governed by a Presbyterial system. The congregation is served by one (female) resident pastor, a church council with one elder and one deacon ministering each of the 31 wards. Apart from governance duties, elders visit congregation members on a quarterly basis to formally invite them to the celebration of the Holy Communion. These house visitations carry a spiritual-supportive character and although set as the ideal, not all elders are able to sustain this practice on a regular basis. Collection of tithes is performed by deacons on a monthly basis. However, because of the growing trend of congregation members donating tithes via electronic bank transfer, monthly visits of deacons are on the decrease. Congregation members with pastoral needs as a result of illness and other pastoral challenges are tended to by the resident pastor on an individual basis as the need occurs.

Worship style falls within the Reformed tradition, which focuses on the preaching of the Word and a structured liturgy that is planned around the theme of the sermon, rendering a recognisably Calvinistic character. Ample time for worship is allocated before preaching commences and both the hymnbook and a growing selection of spiritual songs are used. A well-kept pipe-organ, string and other instruments are used during worship by a dedicated worship team.

The official theological viewpoints of the congregation are conservative in nature when measured against current societal trends regarding mentioned contentious issues.

Congregational life is structured according to an annual programme. Although there are a variety of small group activities during the week, such as two Bible study groups (one adult group and one for senior members) and two catechesis groups for high school learners, it seems safe to suggest that the convergence point for congregational life is the public worship services on Sundays.

As of the second quarter of 2016, only one service is held instead of the usual practice of morning and evening sermons, of which the latter's numbers declined sharply since the late 1990s. This decision also concurred with the decision to not 
employ a second resident pastor, when the position vacated during the first quarter of 2016.

Over the last two decades, a number of activities that previously presented opportunities for congregation members to commune ceased to exist because of poor attendance. These include mid-week prayer meetings, prayer meetings in wards and youth programmes on Friday afternoons and Sunday evenings following the evening sermon. In this way, communion between church members became increasingly dependent upon the service held on Sundays.

Despite changes in attendance patterns, the congregation saw some growth in member numbers over the last two decades. The total number of souls recorded in the 2000 Yearbook of the DRC (2000:367) was 897 compared with 998 of 2021 (Yearbook of the DRC 2021:185). In 2017, the number of souls peaked at 1200, the highest in the congregation's history (Yearbook of the DRC 2017:201). Unfortunately, attendance of public worship remained mediocre at best, seldom exceeding $48 \%$ of the total membership and falling as low as $9 \%$ during school recess when there is no formal catechesis after the sermon (based on Vestry book entries of the first Sunday of the first terms of 2016-2020 [the 5 years prior to COVID-19]) and the first Sunday of the first quarter school recess of the same years. The first Sundays of the first term of a new year are traditionally attended the best and the first Sunday of the first quarter school recess the worst. The best attendance for this period was on 17 January 2016 (48\%) and the worst was on 22 March 2020 (9\%).

Despite mediocre attendance of public worship, a positive attitude towards the congregation in general exists. The pastor, elders and deacons are welcomed into the homes of attendees and non-attendees alike, as experienced during house visitations and pastoral visits. Non-attendees also make regular financial contributions (tithes) to the congregation, as the financial records reflect. Consequently, the congregation remains financially viable, paying the salaries of its eight permanent staff members, as well as all service providers and is able to maintain its facilities, equipment and terrain.

Pre-COVID-19 congregational life in the DRCLE was thus centred on public worship on Sundays, linked to a weekly programme that included abovementioned small group activities - and became over years, the main practical expression of the communio sanctorum.

\section{(Dutch) Reformed perspectives on the notion of communio sanctorum}

Before making observations on the congregational life of the DRCLE mid- and post-COVID-19, a few remarks on the notion of communio sanctorum with special reference to the Dutch Reformed tradition are made.

The notion of communio sanctorum is seated in the confessional basis of the DRC, reaching back to the grassroots confession of faith in the Triune God by early Christianity that became known as the Apostle's Creed or Apostolicum (in DRC circles, also: The 12 articles or simply Credo). Growing from the seed of catechesis and baptismal confession, used widely by the 2nd century, it became the archetype of later Christendom doctrinal confessions (Ashwin-Siejkowski 2009:4, 6; Myers 2018:7) and the basic expression of faith in the Protestant movement of the 16th century.

The Apostolicum confesses faith in the Triune God, Father, Son and Holy Spirit, which is intrinsically linked with the birth and existence of the Christian church (ninth article of the creed). As the late dogmatic, Johan Heyns (1988:363-365) reiterated: the church came into being on grounds of God the Father's decision, with Jesus Christ becoming the origin and the Holy Spirit the maker of a unique Christological community. According to Cranfield (2004), the ninth article of the Aposotolicum follows directly on the confession of faith in the Trinity to recognise that the church is the:

[C]ongregation assembled by the Holy Spirit's work of creating and sustaining faith in Jesus Christ, the company of those who believe in the one true God and who are his people, chosen and called by him not just for their own good but for the good of all humankind. (p. 60)

How the congregation, assembled by the Triune God, was to function in the world was in the Reformed tradition to a great extent informed by notions of a Holy Catholic Church and the subsequent communion of saints.

For Calvin, the communio sanctorum was a pivotal term in understanding the functioning of the local congregation. Whilst for him, 'catholic' in the ninth article denotes the true assembly of Christ in the general sense and not the specific sense of the Roman Catholic Church - and the communion of saints, a transcendent communion between believers' past, present and future - which also gives direction to life in the local church and specifically public worship. According to Calvin, 'the communion of saints found reinforcement for its life and impetus to its social action in the solidarity of public worship' (Petry 1936:231). True to the tenets of the Reformed faith, the Word stands central in public worship, supported by the sacraments and prayers of the societas fidelium. Hence, Petry denotes Calvin's vision of the community of believers as a 'bibliocracy with the cohesiveness and motivating unity of the Word' (Petry 1936:232). This unity of the faith community also means that 'the individual could not withdraw from the common life into selfish isolation' as '... he erred who sought to grow by himself. All were to be whatever they were for each other' (Petry 1936:235).

This inward commitment, however, in no sense implies social withdrawal. On the contrary, the congregation that is edified during public worship, is to share its gifts with society. Therefore, 'the communion of saints was called to play its part in the common solidarity and interdependence of all humanity' and 'social ministration was to be extended regardless of the recipient's merit' (Petry 1936:235). 
Arguably, the outward functions of the faith community featured even stronger with the champion of the Reformation, Martin Luther, who also drew strongly on the notion of the communio sanctorum for the development of his ecclesiology. Being mercifully included in the community of saints through faith, also means being endowed with what Martin Luther denoted as the priesthood of all believers. According to Taylor (1995), the idea of 'sharing' in Christian priesthood, which was embedded in the community of saints according to Luther's ecclesiology, took centre stage. As the ideas of Gemeine (community) or Versammlung (assembly) lived strong in his thinking - as opposed to the German sentiment of Kirche - his emphasis on sharing is understandable. The primary vehicle for sharing is love for God and the neighbour and the primary gift to share is salvation. Sharing however is not limited to the Gemeine, but should most certainly be focused on the 'neighbour' (Taylor 1995:261). Hence, 'the Christian may serve his neighbour with liberty' and should also include those 'on our left hand' (Taylor 1995:261).

Another seminal Reformed document that interprets the Apostolicum is the Heidelberg Catechism. Commissioned by Elector Frederick III, this document was published in January 1563 and pre-dominantly presents the work of co-writers Sacharias Ursinus and Casper Olevianus. In the second section (question and answers 12-85), which is concerned with redemption in Christ and faith, an exposition of the ninth article of the Apostolicum is offered. As a reconciliatory document its approach is somewhat neutral - and even generic - not providing precise definitions of contentious words in the article such as 'catholic' and 'saints', but merely supporting the belief that God called the church into being, that the church binds all believers together and that members are obliged to serve other members of the faith community with their gifts (Sunday 21, question and answer 54-55). Consequently, it is less specific about the outward functions of the church in general and the local congregation in particular, although some of the Scriptural passages provided in support of the ninth article's exposition do support an outward vision.

The social or communal character of the church was further developed by Lutheran theologian Dietrich Bonhoeffer. Bonhoeffer's 1927 Doctoral thesis, 'The communion of Saints: A Dogmatic enquiry into the Sociology of the Church' (originally: Sanctorum communio: eine dogmatishe Untersuchung zur Soziologie der Kirche and translated by Smith [Bonhoeffer 1963]) was a theological attempt to understand the church from the stance of sociology (Du Toit 2016:197). According to Du Toit (2016:202) Bonhoeffer was intent on rekindling the thinking of Martin Luther on the church as community (personsgemeinschaft) versus the institutional character in the Europe of the time. The outward function of the church was evident in the notion of sharing the gifts of God (the Father) with the community and accentuated both the inward and outward social functions of the faith community.
Reflecting on my own experiences of the communio sanctorum in the DRC, I sense that many congregations, under which I include the DRCLE, leans more to the generic and inward stance of the Heidelberg Catechism. The community of believers is thus understood as those who gather for public worship and not necessarily those who 'sought to grow by themselves' (Calvin) or those 'on our left' (Luther). Reciting the ninth article of the Apostolicum every Sunday has by and large then become something of a reductionism, saying that we believe in the koinonia (fellowship) generated by those (few) who still attend public worship, without conjuring up any evangelistic or missional longing for those who are no longer - or have yet to become - part of the faith community. This inward inclination is illustrated by the absence of any particular mission statement or clear strategy about addressing dwindling attendance, but rather accepting the status quo with stoic resignation.

\section{Congregational perspectives on the notion of communio sanctorum}

A purposive sample of 26 congregation members was invited to complete a short questionnaire consisting of four openended questions regarding their views and experiences of the communio sanctorum in general, but also related to COVID-19. Two additional biographical questions were added that showed that the average age of the 23 respondents was 53, of which the youngest was 21 and the oldest 72 . A total of $12(52 \%)$ of the participants were male and $11(48 \%)$ female. As a result of potential difficulties in obtaining legal informed consent, no children were invited to participate. Part of the inclusion criteria also pertained to access to email and active participation in congregational life.Questionnaires and informed consent forms were distributed electronically in the participant's mother tongue, Afrikaans.

The first question invited participants to share their views on the meaning of communio sanctorum in general and the second asked participants to relate some of their personal experiences of the communio sanctorum during 'hard lockdown' (what did you miss the most?). The third question probed participants to share any new experiences of communio sanctorum that were of benefit to them and the faith community during 'hard lockdown'. The final question offered them the opportunity to relate personal observations of new opportunities they saw that should be pursued in the congregation's ministry post-COVID-19, as opposed to merely returning to pre-COVID-19 practices.

Thematic coding of responses yielded the following:

\section{The meaning of communio sanctorum}

All participants strongly associated the community of believers with (Sunday) public worship, where public worship represents the proclamation of the Word, liturgy and, especially, koinonia. A few extended the communio sanctorum to other activities, such as Bible studies and small group gatherings. At least two participants mentioned the 
importance of the sacraments as part of the communio sanctorum. It transpired that the communio sanctorum is viewed as having a strong inward function insofar as its purpose includes mutual edification through spiritual gifts, such as prayer and to support one another spiritually. Only three respondents linked public worship to the 'world'. 'Our being together is not just for ourselves, but also to make Gods' presence visible in the world' (Respondent 3). Another respondent (15) wrote: 'The community of believers has a responsibility towards each other and the rest of the world'. When the community supports one another spiritually 'those who are not yet part of the body of Christ will recognise the mercy of Jesus and praise God'. Respondent 18 stated: 'The communio sanctorum does not exclude the "luke warm"; we hope that when we express our faith, the "luke warm will warm up to Christ"'.

\section{Communio sanctorum and 'hard lockdown'}

The second question provided an opportunity for participants to reflect on the impact (losses) of 'hard lockdown' on their experience of the communio sanctorum. All of the responses indicated that respondents missed the koinonia with fellow believers, some specifically missing the spatial aspect of the church building.

\section{'Hard lockdown' and new expressions of the communio sanctorum}

On the question of what new experiences participants had of the communio sanctorum during this period, responses centred on social media, that is, the digital format of communio sanctorum that became the way sermons were conveyed. Two strands of thinking became visible in responses. The first was that some respondents saw the WhatsApp sermons as a personal lifeline, whilst the second also saw it as a tool for sharing the 'Good News' with friends and family. Some specifically reiterated that the digital community of believers is no substitute for the traditional. 'It was important to keep up with the WhatsApp sermons...but I could not wait to go to church again' (Respondent 16).

\section{New opportunities that should be pursued in the congregation's ministry post-COVID-19}

The final question offered opportunity for a retrospective reflection on any new practices that emerged during COVID-19 that they felt adamant the congregation should pursue in its future ministry.

The majority responses presented a plea for a return to 'how things were'. 'Please, let us just return to the practices we had as a congregation' (Respondent 1 ).

From some of the responses, a sense that COVID-19 signalled permanent changes for the church was also evident. 'I suspect that church has permanently changed. Church attendance will possibly not return to previous numbers' (Respondent 2). Taking the same idea further, another respondent suggested that social media should be used post-COVID-19 to 'lure' the congregation 'back to church' by sending them a 'preview' of Sunday's sermon (Respondent 4). There were also some reservations about the future use of distributing sermons via social media post-COVID-19, as this might 'spoil' congregation members and encourage them not to physically attend sermons. Clear 'discernment' for postCOVID-19 ministry is needed (Respondent 12).

\section{COVID-19, 'hard lockdown' and the Dutch Reformed Church Lichtenburg East}

Viewed in retrospect, the so called 'hard lockdown', which prohibited social movement that engulfed South Africa during March 2020 came as a great surprise for many. Although it was preceded with much uncertainty and speculation, the extent of emergency measures enforced by government was not expected. Preceded by a national state of disaster announced by State President Cyril Ramaphosa on 15 March 2020 (which prohibited public meetings of more than 100 people), a total restriction of movement ('hardlockdown') followed on 23 March and came into effect from $27 \mathrm{March}$. As the national state of disaster still allowed public meetings of 100 or less people, public worship in the DRCLE continued on 22 March 2020, with the Vestry book recording a total attendance of 96 souls.

Irrespective of the fact that lockdown in Europe was by then a reality, it was hard to conceive that such drastic measures would reach southernmost shores. Consequently, no contingency plan in the DRCLE was in place prior to the 'hard lockdown' and when the news broke, immediate measures had to be arranged telephonically by leadership. These were mainly driven by the resolution that although the congregation could not convene physically, sermons should be delivered to members via an alternative avenue. Hence, Sunday (29 March 2020) represented a historical milestone in the DRCLE's 69-year history, when its doors remained closed for public worship for the first time in its existence and a voice recording of the sermon was sent via social media (WhatsApp) to church council members who distributed it in their wards (Vestry book). The WhatsApp platform was chosen as the majority of congregation members had access to it.

All other activities that required physical contact were suspended, pending revisions of emergency level measures by government. Initial reactions by congregation members on these drastic measures ranged from shock and anger to denial. From personal communications with the researcher, it seemed that some experienced high levels of anxiety and disorientation as a result of suddenly being housebound and the possible implications for work and income. Others felt that the government was infringing on the basic rights of citizens by denying them the right to express religious freedom. Altogether, it seemed that many felt overwhelmed by the new situation. This feeling was intensified by the fact that COVID-19 posed a real health risk as news regarding 
national growth in infections and fatalities started to become a reality.

\section{The Dutch Reformed Church Lichtenburg East and prevalent trends mid- and post-COVID-19}

Pertaining to the focus of this article, a number of notable trends, since the lockdown and subsequent relaxing of social distancing measures, emerged in the DRCLE.

Most visible since the 'hard-lockdown', was the physical closing of the congregation's doors and amenities for public gatherings. Communications between the pastor and congregation reverted to telephonic, email and social media platforms, specifically WhatsApp. Public worship was consequently substituted by the distribution of two voice recordings on Sundays. The first was congregation news, which was normally distributed at sermons in the form of a newsletter. A second recording, which was limited (because of file-size constraints), contained the sermon. Although analysis of sermon content falls outside of the scope of this article, it can be mentioned that recordings mainly focused on the sermon itself, with no distinguishable focus on liturgical elements. In this process, church council members (elders and deacons) played a pivotal role in connecting congregation members, attempting to reach everyone with sermons. As many church council members already had their ward members as WhatsApp groups, distribution of communication occurred via the pastor distributing it amongst council members who re-distributed it to ward members. Soon enough, individuals who did not receive any communication from church council members contacted the pastor, who created an additional mailing list. Amongst these individuals were persons, not formally enrolled as members, but who worshipped with the congregation before COVID-19. One of the most noticeable (and surprising) trends, regarding the distribution of sermons, is that the pastor received a number of requests from inactive members to be added to the mailing list. These were typically members who did not (for reasons unknown) attend public worship anymore, but also felt the need to receive sermons during 'hard-lockdown'.

A second trend emerging during 'hard-lockdown' was the substantial number of congregation members who experienced material need because of shortfalls in income related to COVID-19. These needs ranged from not having food on the table to funds needed to pay rent, medical treatment and other essential services. When these needs were communicated to the congregation, members responded positively by donating funds and by delivering food and other essentials to the church hall, which in the early days of COVID-19 resembled a distribution centre for emergency parcels. In this way many, congregation members were able to survive some of the immediate crises imposed by the pandemic.

A third notable trend during the initial and most severe period of COVID-19 was feedback from church council and congregation members on sermons. Not only did these responses communicate sincere gratitude for the privilege of receiving sermons during lockdown but individuals also commented on the content of sermons and how it was of particular meaning to them. Some also reported the distribution of sermons amongst personal networks in order to encourage them. During pre-lockdown times, reflection and feedback on sermons were something of a rarity, but under these new and trying circumstances there were strong evidence of engagement with and appreciation of the content of sermons.

The 'hard-lockdown' was to end towards the end of April 2020, lasting just over a month, as opposed to the 2 weeks initially envisaged by government. A new, albeit partially digital sense of community (koinonia), emerged in the DRCLE. Although the church doors were closed, the Word was still proclaimed and positively received by the faith community. Diakonia, although formally present and managed before, was now offered by a larger group of congregation members and on a more personal level. Above all, the voices of previously inactive congregation members were heard, as seen in requests to be included in the mailing list to receive sermons. A new appreciation for the gospel and the wish to share it with others also emerged.

With much anticipation the faith community awaited the relaxing of restrictions in order to learn if public worship could resume as before. The news that only 50 people would initially be allowed at religious gatherings was met with disappointment. The church council resolved to make public worship accessible to as many people as possible on Sundays, by arranging two sermons in order to accommodate at least 100 worshippers per Sunday in anticipation of large numbers wanting to attend public worship. With all prescribed and legal protocols in place, public worship resumed in the DRCLE on 07 June 2020 with a maximum of 50 worshippers allowed per sermon. However, much to the disappointment of leadership optimal attendance figures for the early sermon did not materialise and saw the congregation reverting to one sermon in the usual time slot, hosting the allowed number of 50 attendees from August.

Since October 2020 and based on further relaxation of restrictions, 100 worshippers per sermon were allowed. This relaxation was, however, short lived when the second wave of COVID-19 swept the country, leading to a second 'hard lockdown' banning all public worship from 31 December 2020 to 30 January 2021. After another month of a maximum allowance of 100 worshippers, social distancing measures allowed for 250 worshippers from 01 March 2021. For the ensuing eight Sundays of March and April however an average of 171 souls was recorded, which translates to $17 \%$ of the total congregation and $68 \%$ of the allowed maximum. Initial post-COVID-19 figures thus reflected an even further decline in attendance of public worship when compared with pre-COVID-19 trends. This suggests that COVID-19 might 
have further challenged the communio sanctorum in the DRCLE and that hopes of a substantial collective return to public worship were misplaced.

The question hence arises what some of the reasons for this might be. One might consider that older congregation members harbour legitimate fears about public gatherings because of age-related COVID-19 vulnerabilities as do families with small children and therefore refrain from resuming church attendance. However, considering the fact that community life (economic, school and general activities) was resumed in large numbers as legislation allowed, it stands out as odd that the same cannot be said about faith gatherings. This may suggest that the banning of public worship was not really an existential crisis for congregation members. At least not the type that brought the faith community to a reappraisal of the privilege of the communio sanctorum that would motivate them embrace it when it represented itself and to motivate others to follow suit.

\section{Reflection and conclusion}

For 69 years, the DRCLE has been part of the 369-year-old heritage of the DRC in South Africa. Today it serves the spiritual needs of one of the minority ethnic and language groups in the country. On a subconscious level, it may even be regarded as a 'safe haven' and 'familiar surroundings' for its members who have been occupying the same liturgical space for nearly 70 years. However, judged by its dwindling statistics, the bigger DRC family is regarded by some as 'dying' - urging this church family to consider ways of revitalisation and to nurture future growth. The dawn of COVID-19 could, therefore, be interpreted as a kairos moment on many levels, least of all as an opportunity to reappraise the privilege of communio sanctorum and to stimulate it as COVID-19 regulations became relaxed.

Initial observations of post-COVID-19 congregational life, however, lead the researcher to suspect that the DRCLE is merely attempting to regain pre-COVID-19 homeostasis, in this way aligning with historic DRC tendencies to lean towards a reductionist view of the community of believers. This was confirmed by members' views of the communio sanctorum that showed an inward preference for the sake of koinonia and a strong yearning to return to the 'old ways' - or then - 'as we were'. Whilst social media was a lifeline amidst the disruption of the normal, it was deemed no substitute for the koinonia known to the faith community in the space of the church building. This inward inclination, however, in no way diminished the resilience of the congregation during 'hard-lockdown', as seen in the embracement of a form a digital communio sanctorum and its practical demonstration of diakonia by making available food and funding for those who needed it during the initial stages of COVID-19. Whilst the latter was an extension of a sustained historic practice, the former is a demonstration of the congregation's ability to adapt to foreign circumstances and its collective will to ensure the spreading of the gospel.
Sadly, there were however missed opportunities. Arguably the biggest so far has been the failure to pursue contact made by those 'to the left' during 'hard-lockdown' further. Surely, this signalled an openness by inactive members to become reconnected to the faith community. Whilst one can argue that these signals were born from personal crises experienced because of COVID-19, this congregation might have done well by seizing the opportunity to seek out those who have gone astray (Mt 18:12). At the least, these signals sparked the hope that there are inactive members whose memories of the church were stirred by the COVID-19 crisis - and the church should reach out to them in an active and orchestrated fashion in order to restore the community of the faithful. Then, there is the most obvious of all, namely the failure of the collective faith community to re-embrace opportunities for communio sanctorum in light of the sad experience of losing it temporarily.

In the light of this one can only hope that faith communities will, in the aftermath and ongoing struggle with COVID-19, start seeking 'what we ought to be'. In this regard, at least two suggestions can be made. Firstly, the DRCLE's reductionist notions of the communio sanctorum need to be restored to its Reformed 'settings' that were not just focused on those who were actively part of the faith community, but those who left and those who were yet to be reached with the gospel. Secondly, COVID-19 should be reframed within an existential reading as more than a disruption of the known by asking: As we were or seeking what we ought to be? Starting to ponder the latter, might render COVID-19 as more than a disruption, but an opportunity to bring the communio sanctorum to its potential fullness.

\section{Acknowledgements Competing interests}

The author declares that he has no financial or personal relationships that may have inappropriately influenced him in writing this article.

\section{Author's contributions}

A.R.B. is the sole author of this article.

\section{Ethical considerations}

Ethical approval to conduct this study was obtained from the Theology Research Ethics Committee (TREC) of North-West University on 10 May 2021. Ethics number: NWU-0076021-A7.

\section{Funding information}

This research received no specific grant from any funding agency in the public, commercial or not-for-profit sectors.

\section{Data availability}

Data sharing is not applicable to this article as no new data were created or analysed in this study. 


\section{Disclaimer}

The views and opinions expressed in this article are those of the author and do not necessarily reflect the official policy or position of any affiliated agency of the author.

\section{References}

Ashwin-Siejkowski, P., 2009, The Apostles' Creed: And its early Christian context, Bloomsbury Publishing Plc., London.

Bonhoeffer, D., 1963, The communion of Saints: A dogmatic enquiry into the sociology of the church, transl. G.R. Smith, Harper \& Row Publishers, New York, NY.

Brunsdon, A.R., 2017a, 'Towards a pastoral care for Africa: Some practical theological considerations for a contextual approach', in S.P. Van der Walt \& N. Vorster (eds.), Reformed theology today: Practical-theological, missiological and ethical Reformed theology today: Practical-theologic
perspectives, pp. 107-122, AOSIS, Cape Town.

Brunsdon, A.R., 2017b, 'Misconstrued identities mustfall: Collective identity formation in the current South African context: A practical theological perspective', HTS Teologiese Studies/Theological Studies 73(2), a4888. https://doi.org/10.4102/hts. v73i2.3822

Chavez, C., 2008, 'Conceptualizing from the inside: Advantages, complications, and demands on insider positionality', The Qualitative Report 13(3), 474-494.

Cranfield, C.E.B., 2004, The Apostles' creed: A faith to live, Bloomsbury Publishing PIc., London.

Dutch Reformed Church, 2000, Yearbook of the Dutch Reformed Church, Issue 151, Tydskriftemaatskappy, Wellington.

Dutch Reformed Church, 2017, Yearbook of the Dutch Reformed Church, Issue 168, Tydskriftemaatskappy, Wellington.

Dutch Reformed Church, 2021, Yearbook of the Dutch Reformed Church, Issue 172 Tydskriftemaatskappy, Wellington.

Du Toit, D.J., 2016, 'Virtualiteit in Dietrich Bonhoeffer se Sanctorum Communio (Virtuality in Dietrich Bonhoeffer's Sanctorum Communio)', PhD thesis, University of Pretoria.

Forster, D., 2016, 'Dangerous echoes of the past as church and state move closer in South Africa', The Conversation, October 16, viewed 03 March 2021, from https:// theconversation.com/dangerous-echoes-of-the-past-as-church-and-state-movecloser-in-south-africa-65985.

Gaum, F.M., 1997, Die verhaal van die Ned Geref Kerk se reis met apartheid (The narrative of the DRC's journey with apartheid), Hugenote Uitgewers, Wellington.
Gaum, F.M., 2002, 'Lang reis met apartheid (Long journey with apartheid)', in P. Coertzen (ed.), 350 jaar gereformeerd (350 years reformed), pp. 236-243, Barnabas, Bloemfontein.

Heyns, J.A., 1988, Dogmatiek (Dogmatics), NG Kerkboekhandel, Cape Town.

Heyns, L.M. \& Pieterse, H.J.C., 1990, A primer in practical theology, Gnosis, Pretoria.

Kenny, P., 2016, 'Reinstatement of South Africa's Dutch Reformed Church likened to "return of the prodigal son"', WCC News, viewed 03 March 2021, from https:// www.oikoumene.org/news/reinstatement-of-south-africas-dutch-reformedchurch-likened-to-return-of-the-prodigal-son.

Leonard, C., 2012, 'The slow and steady death of the Dutch Reformed Church', Mail \& Guardian, April 05, viewed 07 March 2021, from https://mg.co.za/article/201204-05-the-slow-and-steady-death-of-dutch-reformed-church.

Myers, B., 2018, The Apostle's creed: A guide to the ancient catechism, Lexham Press, Bellingham.

Oosthuizen, J., 2019, 'Afrikaanse kerke loop leeg' (Afrikaans churches are losing members), Voertaal, January 31, viewed 05 April 2021, from https://voertaal.nu/ afrikaanse-kerke-loop-leeg/.

Petry, R.C., 1936, 'Calvin's conception of the "communio sanctorum"', Church History 5(3), 227-238. https://doi.org/10.2307/3160786

Raper, P.E., Möller, L.A. \& Du Plessis, L.T., 2014, Dictionary of Southern African place names, Jonathan Ball Publishers, Johannesburg.

Statistics South Africa (Stats SA), 2020, Mid-year population estimates, viewed 05 April 2021, from http://www.statssa.gov.za/publications/P0302/P03022020.pdf.

Steyn, M., Wepener, C. \& Pieterse, H., 2020, 'Preaching during the Covid-19 pandemic in South Africa: A grounded theoretical exploration', International Journal of Homiletics 4, 1-20.

Strauss, P.J., 2019, 'The Dutch Reformed Church is continuously changing: Revision of the church order of 1998', HTS Teologiese Studies/Theological Studies 75(4), the church order of 1998', HTS Teologiese Stud

Strauss, P.J., 2020, 'Die Nederduitse Gereformeerde Kerk se afskeid van apartheid: Cottesloe (1960) -'n voorloper van "Kerk en samelewing" (1986; 1990)? (The Dutch Reformed Churches' farewell of apartheid: Cottesloe (1960) - A precursor to "church and society" (1986; 1990)?', In Die Skriflig/In Luce Verbi 54(1), a2529. to "church and society" (1986; 1990)?',
https://doi.org/10.4102/ids.v54i1.2529

Swinton, J. \& Mowat, H., 2016, Practical theology and qualitative research, 2nd edn., SCM Press, London.

Taylor, S.M., 1995, 'Sharing within the community of saints: A study of Luther's ecclesiology', American Baptist Quarterly 14(3), 260-269.

Van der Merwe, J.M., 2002, "n Nuwe koers wat lei tot 'n nuwe kerk: Die NG Kerk en die ontstaan van die Afrikaanse Protestantse Kerk (A new direction that led to new church: The DRC and the inception of the South African Protestant Church)' in P. Coertzen (ed.), 350 Jaar Gereformeerd, pp. 421-429, Barnabas, Bloemfontein 